\title{
HIV/AIDS AND HUMAN SUFFERING: WHERE ON EARTH IS GOD?
}

\author{
Ernst M Conradie \\ Department of Religion and Theology \\ University of the Western Cape
}

\begin{abstract}
This article reflects on the classic theodicy problem in relationship with HIV/Aids. It first offers some general comments about the very need to address the theodicy problem. A next section offers an analysis of various sources of human suffering which is then related to an overview of some of the dominant theodicies in current theological discourse. These discussions are brought together in a final section which investigates various possible answers to the question: Where is God amidst the suffering associated with the HIV/Aids pandemic? The article concludes that one of the many challenges that HIV/Aids pose to Christian communities is to offer a plausible account of each aspect of the Christian faith.
\end{abstract}

Key Concepts: Theodicy, suffering, Christian theology, HIV/Aids

\section{Introduction: The Challenge of HIV/Aids to Christian Theology}

South Africans are quite familiar with the many challenges posed by the HIV/Aids pandemic. The list of these challenges is clear and stark: The need for a network of caregivers with various forms of expertise (medical, social, psychological, religious) that can cope with millions of infected and affected people, the quest for appropriate medical treatment and HIV-immunisation, the availability of pharmaceutical drugs and the financing of such medical treatment (by the state and international donors), the immense economic impact of illness and death associated with HIV/Aids, effective campaigns for moral formation and education to prevent the further spreading of the virus, the disruption of family and social life for decades to come, and so on and so forth.

What is needed to address these challenges is something like a rainbow alliance in which literally all sectors of the South African society from various perspectives and persuasions (red, green, brown, purple) will have to be involved. ${ }^{1}$ Churches in South Africa (the purple sector) have made significant contributions at various levels in this regard (e.g. counselling those who have been stigmatised, nursing the sick and the dying, nourishing the hungry, looking after orphans, participating in HIV/Aids awareness campaigns, offering sensitising and training programmes). ${ }^{2}$ These contributions are by now fairly welldocumented. ${ }^{3}$ The responsibility of churches to make such contributions and their immense

\footnotetext{
See Jacklyn Cock (1992) for a similar proposal that such a rainbow alliance is needed to address environmental issues in South Africa.

2 See, for example, the extensive work done by the Ecumenical Foundation of Southern Africa (EFSA) and the informative reflections by Greyling (2003). Byamugisha et al (2002) collected a number of stories of hope on church-based responses to HIV/Aids in three southern African countries.

3 This task was also the focus of a conference on "The Church and HIV/Aids" held at the University of the Western Cape in 2001.
} 
potential to do so given their institutional networks, infrastructure, grassroots support, skilled leadership and established moral traditions have been reiterated in literature on HIV/Aids. ${ }^{4}$ The role of theological institutions to contribute to adequate training in this regard has also been emphasised. ${ }^{5}$

If I may offer one critical observation in this regard, it remains a question whether the contributions from the church have fathomed the uniqueness of what Christianity may offer in this regard. Are churches not simply doing what others have also been doing and in many cases have been doing better? Let me mention three areas: What can a pastor say to a young adult who is dying from Aids-related diseases? What can the Christian hope in a God - who transcends life and death itself - offer in such a situation? What is the relationship between health and healing and the Christian message of salvation in Christ? The healing ministry of the church certainly includes but should also transcend other dimensions of health. If the spread of HIV/Aids is deeply tainted by patriarchal attitudes, what can a Christian assessment of human sin, God's gracious judgement on sin and the strangely salvific message of the cross offer in response to such forms of patriarchy? In my view the Christian faith has far more to offer than what many Christians may realise - if Christians do not lose the nerve to confess the particularity of their faith.

Christian theologians have made numerous contributions to support churches in their task of responding to the HIV/Aids pandemic by developing liturgical and resource material, by offering leadership training and by reflecting on appropriate forms of pastoral care and counselling. In these ways Christian theology has responded to the challenges posed by the HIV/Aids pandemic. Clearly, it has much to contribute in this regard. However, it is less clear that Christian theologians have been able to discern the critical challenges that the HIV/Aids pandemic pose to Christian theology itself. The question has to be whether our theologies are adequate or whether HIV/Aids has exposed some of the fault lines in our theologies. Subsequently, the purpose of this paper is to address the challenges that the HIV/Aids pandemic pose to Christian theology.

In this contribution I will focus on one of these challenges, namely the crucial problem of human suffering itself. Theologically the question that has to be addressed here is reflected in the title of the essay: Where on earth, if anywhere, is God amidst the immense human suffering related to the HIV/Aids pandemic? ${ }^{6}$ Does God not see all the pain and suffering? Does God not hear our cries? What, if anything, is God doing amidst such suffering - the trauma and stigma of discovering that one is HIV/Aids positive, the ongoing battles concerning the availability of medical treatment, the agony over one's shortened life expectancy, the bodily pain caused by diseases during the terminal Aids phase, the disruptive economic and social impact of such sickness, the anxiety over the approaching moment of death, the bereavement associated with death, and the long-term impact of multiple deaths on family life, support systems, and the moral fabric of community life where juvenile delinquency, rape, gangsterism and crime (and the suffering of the victims associated with these) should be expected if millions of children will be growing up without parents in decades to come. What is the God of Jesus Christ doing to address all these

See, for example, Greyling 2003:125-126, also Yamamori, Dageforde \& Bruner (2003).

See Maluleke (2001) and especially the volume of essays by Dube (2003).

The focus of this contribution will be on human suffering. There are several connections between the human and environmental dimensions of the HIV/Aids pandemic which cannot be explored here. Suffice it to say that human suffering is not the only form of suffering. An ecological theology would need to relate human suffering to both the suffering of God and to the suffering of sentient animals. 
manifestations of suffering? This is, of course, the classic theodicy problem, articulated within a new context.

Given the enormity of the problem, this is perhaps a question that can be addressed authentically only by those in the midst of the pandemic and not from a safe academic distance. Since we are all affected, if not infected, by the virus, I nevertheless hope to offer a contribution in this regard through some theological reflection and analysis. In the discussion below I will start with a few general comments about the very need to address the theodicy problem. A next section offers an analysis of various sources of human suffering which is then related to an overview of some of the dominant theodicies in current theological discourse. These discussions are brought together in a final section which investigates various possible answers to the question: Where is God amidst the suffering associated with the HIV/Aids pandemic?

\section{The Ambiguous Need to Address the Theodicy Problem}

The term "theodicy" indicates the need to justify God's very existence given the prevalence of suffering , to declare ("-dicy" is derived from the Latin dicere, "to say") why God would allow such suffering, to explain how a compassionate and powerful God could be just if there is so much suffering in the world.

The theodicy problem is much easier to formulate than to answer. In fact, any brief overview of theodicy debates over twenty centuries of Christian theology soon reveals the disparateness and inconclusiveness of these debates. ${ }^{7}$ Some would conclude that this clearly indicates that the problem cannot be resolved - and that God cannot and does not exist if there is so much suffering, or that God is absent, perhaps far away in heaven, or that history is controlled by fate, not God, or that God is either not powerful or not compassionate. The cynics may shout, with Dr Rieux in Albert Camus' The plague, upon witnessing a child die of the bubonic plague: "I refuse to participate in a scheme of things which tolerates this." Even those who maintain a belief in God may act as if God's presence does not contribute anything to the way in which human suffering is addressed. This may well apply to the church in South Africa too - wherever it addresses suffering related to the HIV/Aids pandemic without any reference to God. Others would maintain that the conceptual problem is indeed irresolvable. We as human beings would never be able to comprehend God's ways, given the finitude of our own knowledge, wisdom and power. Yet others would question the way in which the problem is formulated. Who are we to offer a justification of God's existence? Should we not focus, instead, on God's justification of us as sinners (God's word of forgiveness)?

This would indicate that the theodicy problem should not be addressed as a speculative and quasi-logical one, but as a theological and, more specifically, a soteriological and a Christological one. At best, the problem of suffering emerges within the context of the Christian confession of God's providence. The question is therefore not so much a speculative one of why God allows suffering but one of where God is amidst the suffering (calling for a particular theology of place) and what God is doing to address the suffering

\footnotetext{
There is an immense volume of theological literature on the theodicy problem. It may be argued that the problem of suffering has dominated almost all theological agendas since World War II. Amongst the available literature within the reformed tradition, the contributions by Hall (1986), Moltmann (1974) and Van de Beek (1984) may be mentioned. I have also benefited from the work of Richard (1992) and Surin (1986).

$8 \quad$ See Beker 1987:22.
} 
(as it is formulated in the title of this contribution). ${ }^{9}$ However, one must immediately acknowledge that God's response to (human) suffering poses an as difficult problem in the context of the doctrine of providence as in any other context.

There are a number of characteristic tensions in any attempt to provide an answer to the theodicy problem. All theodicies have to grapple with these tensions and most tend to emphasise one of the following polar opposites more than the other:

a) In its classic form the theodicy problem is formulated in terms of the tension between

God's love and God's power. ${ }^{10}$ How could a God who is both omnipotent and a God of love allow human suffering to continue unabated? After all, if God is indeed omnipotent, God should be able to do something about such suffering. And if God is indeed compassionate, God would not want people to suffer. While some forms of suffering may be inevitable and compatible with what is ordinarily understood by compassion, loving parents would never allow their child to suffer excessively - and to die as a result - if they are able to take away such suffering.

Some theodicies are able to defend God's love in the face of suffering but are unable to account for God's power. One example would be a form of Manicheist dualism where the existence of evil is ultimately regarded as something beyond God's control. By contrast, many theodicies fail to explain why suffering could continue if God is indeed a God of love. In one notorious example suffering is regarded as God's righteous punishment for sin. But would a loving parent punish a child that much? Clearly, both the power and the goodness of God call for further conceptual clarification.

b) The classic formulation of the theodicy problem may be criticised for its quasi-logical approach to provide explanations for human suffering. Many pastors would intuitively refrain from providing easy or more sophisticated explanations in response to questions about human suffering. Some may argue that no explanation of suffering would ever be adequate because all explanations (of evil) would justify what is unjustifiable. ${ }^{11}$ Instead, they would emphasise the spiritual value of silence, of listening and of lament. It requires human humility to receive adversity from God's hand because we cannot always understand God's will in this regard. Trust in God's providence sets us free from all undue anxiety and care.

Despite its profound wisdom, this approach is difficult to sustain indefinitely. If silence is the final and only answer, this would leave the impression that God is condoning such continued suffering. Then the theodicy problem may well be raised with a certain vengeance: If the immensity of human suffering is taken into account, is God not perhaps angry, frivolous, ignorant, absent, dead or non-existent? In response, many would ague that evil should be clearly exposed and that an active resistance against evil is far more important than speculation about the origins of evil. Perhaps one may suggest that this is the pathos of human existence: We are inextricably bound to ask and answer questions about the origin of evil and suffering even when we know very well that we can never answer such questions adequately. Theodicies therefore have to steer between the polar opposites of silence and (rational) explanations. If it cannot answer the theodicy problem, a pastoral theology can at least repeat the question,

9 See also the "when" in the title of Rabbi Harold Kushner's acclaimed book, When bad things happen to good people (New York: Avon Books, 1981). Beker (1987:83) observes that Christians may also have to ask: Why do good things happen to bad people?!

10 See especially Van de Beek (1984) for an investigation of each of these approaches to the theodicy problem.

11 See Surin 1986 
clarify what is at stake in the question, show how acute and deeply penetrating the question really is and, with the millions who suffer, pray for a response from God. ${ }^{12}$

c) Theodicies and theological expositions of God's providence have to maintain a tension between an emphasis on God's responsibility and human responsibility. On the one hand, evil should not be ascribed to something (fate, matter, human decision making) beyond God's control. That would comprise God's omnipotence and lead to dualism. On the other hand, ascribing everything to God would compromise human freedom and responsibility. In the doctrine of providence this tension is traditionally formulated under the rubric of divine accompaniment (concursus).

It would clearly be wrong to put all the emphasis on God's responsibility. That could easily become an excuse for human laziness, an unwillingness to accept responsibility, or a form of fatalism (whatever will be, will be - and that may be accepted as God's will; everything comes from God's hand). This would encourage an attitude of acquiescence, apathy, submissiveness and resignation. Such a fatalist acquiescence is contrary to the Christian notion of a personal God who may be approached through prayer.

By contrast, an emphasis on human responsibility only would be spiritually empty. It would underestimate the seriousness of the predicament in which many people find themselves. It could lead to an anxious or zealous striving to establish the reign of God through our own good works. Often such an approach is born from a scepticism regarding God's presence in the world. If God is either dead or powerless, we have to address human suffering through our own collective efforts. This may encourage either triumphalism (activism) or resignation, depending on one's present position of power. Tragically, when the realisation dawns that suffering and death is indeed beyond the control of finite human beings, such imperatives leave many with a sense of disillusionment and disempowerment. Responsibility without any grounds for hope is a burden too great to bear. It cannot motivate the change of attitude and praxis that is needed.

On the basis of these observations it may be possible to develop a grid of eight logically possible theodicies. I will refrain from such an exercise though. Instead, as I will suggest in the next section, it is crucial to take the various sources of human suffering into account.

\section{Sources of Human Suffering: A Theological Assessment}

Any adequate theological response to human suffering requires a theological assessment of human suffering and more specifically of the sources of human suffering. In what follows below I will offer an analysis of some of the sources of human suffering. This analysis is not just phenomenological but specifically theological in orientation in that the various sources of suffering are correlated with typical images of God. Moreover, it locates human suffering within the soteriological tension between human sin and salvation from sin. In each case the generalised analysis of human suffering will also be related to the HIV/Aids pandemic.

a) Some forms of human suffering are a function of what may be called "natural suffering". Not all suffering is the result of human sin. It is important to acknowledge that there has been suffering, violence, decay, the death of individual specimens, and the

12 See Van de Beek (1986:121) who maintains that his book Waarom? (Why?) is not an attempt to answer the question but to express the question anew. 
extinction of species since the emergence of life on earth. ${ }^{13}$ This also applies to (human) mortality. Contrary to the dominant teaching in the Christian tradition, it should be clearly acknowledged that biological death did not enter the world merely as a result of human sin. Sin is the sting of death, not its physical cause. ${ }^{14}$ Moreover, microbiological research shows that all cells have a limited lifecycle. Cells are programmed to die and this is actually crucial to ensure the viability of any organism. Mortality forms an integral part of the biological structure of life. Indeed, pain, fragility and vulnerability seem to be inescapable aspects of the material world. New life on earth can arise only through the death of others.

This suggests that there is a "darker side", a "shadow side" (Barth), a tragic dimension to creation. This may be related to the finitude of human existence which is a necessary function of life. God has created a world in which there is both order and chaos, birth and death, rationality and contingency, order and freedom, risk and vulnerability. ${ }^{15}$ This shadow side cannot be called evil and may be considered part of God's intrinsically good creation.

However, there also seems to be something inherently violent and destructive in the cosmos. One may consider the indescribable ferocity that is evident in earthquakes, volcanic eruptions, black holes and collisions between objects in space. Likewise, the processes of evolution seem to be incredibly wasteful, condemning most emergent forms of life to early extinction. Natural selection appears to be replete with pain, injustice, contingency and spillage. It eliminates ruthlessly and mindlessly all those who are not "fit" to survive and to reproduce. ${ }^{16}$ Nature is ambiguous. She is our mother and our enemy. She brings forth thorns and thistles. Moreover, there seems to be something menacing and malicious in the world of nature. Were there not snakes in the Garden of Eden too? How should we account theologically for floods and droughts, famine and abundance, health and sickness, life and death?

These observations raise some serious theological questions. Are these forms of violence God's will? Did the Creator not foresee the immense suffering that would be prevalent in the created order? Is God really good? Why did God not order the world in such a way that God's creatures would be protected from such suffering and immune to human sin and evil? How on earth could the Creator condone such violence and suffering? How can the goodness of creation be affirmed if suffering formed an integral part of the created order from the very beginning? Can we call death good? This is the bitter riddle of God's good creation. Indeed, how dare God declare creation to be good?

Several aspects of the suffering related to the HIV/Aids pandemic may be considered a function of such natural suffering. One may mention the very existence of destructive and contagious viruses (including those causing influenza and measles) that have killed millions of people throughout history. One can scarcely argue that such viruses are the result of human sin. Does there have to be such destructive viruses in God's good creation? If death is a necessary function of life, death as a result of Aidsrelated diseases would count as one manifestation of natural suffering. The most important difference would be that persons who die from Aids-related diseases typically

13 See Pannenberg ST 3, 1998:559 and Tillich ST 2, 1957:79 for a discussion of suffering as the result of finitude in distinction from suffering as a result of evil.

Tillich ST 2, 1957:67-68.

5 Migliore 1991:101.

16 Haught 2000:3-6. 
die prematurely and not in ripe old age. This makes it far more difficult to come to terms with the biological inevitability of human mortality. A theological response to HIV/Aids therefore requires an adequate "theology of life" ${ }^{17}$ - and of death.

b) A closely related form of suffering is the product of what may be called contingency. Here one may think of accidents, which occur often enough, but for which no person could be held directly accountable. Such contingency is sometimes ascribed to fate or to a divine being who controls contingency but who is rather arbitrary, indifferent, fickle, frivolous, meddlesome or capricious. Humans are subjected to the whims of such a divine being. Accordingly, religion is a way to placate the divine being, a form of quibbling and bargaining to ensure the favouritism of the gods. ${ }^{18}$

It is not always easy to distinguish between such "pure" accidents, errors of human judgement, human negligence, high-risk behaviour and the result of malicious human intent. This may be illustrated with some examples: Suffering caused by earthquakes could be regarded as function of natural suffering, but not if a person fails to adhere to building regulations in a high-risk zone, or if earth tremors are caused by long-term mining activities. A person who has contracted HIV through blood transfusion may be considered a victim of an "accident", but not if there was overt negligence in the administration of blood banks. A doctor who has pricked herself in an emergency operation to save the life of a person and who contracted HIV/Aids in the process may well regard this as an accident that could not be prevented. This would probably serve as the best example of such a form of human suffering, unless the doctor was clearly negligent and did not take the necessary precautions or treatment which may have been available.

c) We are confronted with many all too familiar manifestations of evil in the world: The evils of injustice, slavery, oppression, enslavement, hatred, alienation, conflict, corruption, destruction, environmental degradation, cruelty, rape, induced suffering, and untimely death. ${ }^{19}$ While death and natural suffering may be given with the goodness of creation, these manifestations of evil are typically caused by human beings themselves. One of the core Christian convictions is that these many manifestations of evil cannot ultimately be derived from Godself (monism), from a power (for example Satan or fate) that is beyond God's reach (dualism) ${ }^{20}$ or from the finite material world itself (e.g. a Manichaeist denouncing of bodily existence or human sexuality where the emergence of good and evil is related to the duality of spirit and matter). Such explanations for the origins of evil can only lead to human exculpations. The world of finite, dependant and

17 See the programme of the World Council of Churches towards such a theology of life, with many helpful contributions (e.g. Brinkman 1994, 1999, Granberg-Michaelson 1994, Rasmussen 1994, Robra 1996, de Santa Ana 1995) and my own contribution in this regard (Conradie 2001). See also the essay by Ruele (2003) which relates a theology of life explicitly with HIV/Aids.

18 Bosch (1974:86) comments, with reference to John Mbiti, that God is utilised instead of worshipped in this way. Likewise, the gospel is sometimes packaged to propagate that "Things go better with Jesus!"

19 For Welch (1990:159) untimely death ('death caused by human folly or evil, by torture, environmentally induced cancer, war, occupational hazards or malnutrition'), needs to be resisted, not death itself.

20 See also the excellent essay by David Bosch (1974:62-91) on monist and dualist approaches to the existence of evil, with specific reference to African theology. Bosch suggests that traditional religions in Africa have tended to see good and evil as two sides of the divine being: As long as God stays far from us (God's transcendence) and does not interfere with human existence, then God may be considered to be good. The God who comes to close to us (God's immanence) is dangerous and may cause humans harm. African myths suggest that God has withdrawn himself from humans in primeval times and this has been a blessing. Communion with God is not considered to be something desirable. 
contingent existence has not become evil due to its finiteness or brevity. ${ }^{21}$ It is primarily through the action of human beings that evil entered the world. Evil remains an enigma; it is something that ought not to be, does not have to be, but nevertheless is. ${ }^{22}$ Our natural inclination is to shift the blame for evil unto someone or something else. While there is a widespread fascination with evil in contemporary culture, there is also a marked eclipse of the classic Christian doctrine of $\sin ^{23}$ It is easy enough to recognise the pervasiveness of evil; it is less easy to accept responsibility for such evil. As Luther insisted, this is perhaps the final sin of humanity: To stubbornly refuse to concede the obvious truth, namely that we human beings have to accept the primary responsibility for the evil that surrounds us. ${ }^{24}$ This is expressed in the Christian confession that human beings - all human beings - are sinners. Human sin is, if anything, the origin and root of evil. Evil is the effect of $\sin$ in the world. ${ }^{25}$ This confession suggests that other explanations of the origin of evil have to be resisted, since this may tempt us to justify ourselves and to shift our responsibility upon God, the devil or the material world. ${ }^{26}$ The confession that we are ultimately responsible for sin constitutes a refusal to be drawn into attempts to explain the origin of sin in any way that will let humans off the hook.

Suffering may be the result of the devastating effects of one's own sins, that is, of a self-inflicted act of human self-destruction. This may have an impact on one's body, one's family, one's community, one's immediate environment and estrangement from one's own sense of self-identity. Within the context of the HIV/Aids pandemic it would be unwise to evade this recognition. In the end, a cure may be found for Aids, but human sin is not curable. ${ }^{27}$ Some "victims" of Aids contracted the HI-virus through sexual promiscuity, visiting prostitutes, high-risk social behaviour, a foolish failure to take the necessary precautions against contracting the diseases and so forth. Such persons are indeed the victims of their own sins. They are victims in the general sense that we are all (including HIV-negative persons) the victims of our sins but also in the specific sense that they become ill, that there is immense suffering in the process and that they may well die as a result. However, from a Christian perspective on the doctrine of sin, they are hardly the "innocent" victims of an externally-infused disease that they are sometimes portrayed to be.

d) It is necessary to emphasise both human responsibility for sin and human victimisation by the sins of others. The manifestations of evil listed above may also be manifested in the form of "being sinned against". ${ }^{28}$ People often endure suffering as a result of sins

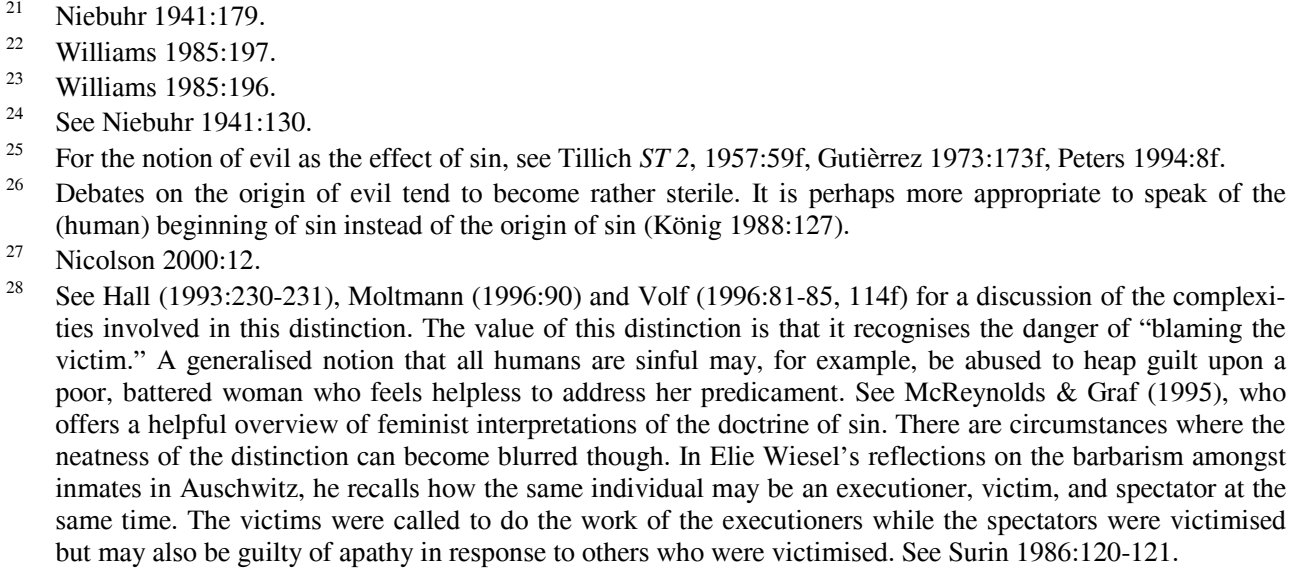

28 See Hall (1993:230-231), Moltmann (1996:90) and Volf (1996:81-85, 114f) for a discussion of the complexities involved in this distinction. The value of this distinction is that it recognises the danger of "blaming the victim." A generalised notion that all humans are sinful may, for example, be abused to heap guilt upon a poor, battered woman who feels helpless to address her predicament. See McReynolds \& Graf (1995), who offers a helpful overview of feminist interpretations of the doctrine of sin. There are circumstances where the neatness of the distinction can become blurred though. In Elie Wiesel's reflections on the barbarism amongst inmates in Auschwitz, he recalls how the same individual may be an executioner, victim, and spectator at the same time. The victims were called to do the work of the executioners while the spectators were victimised but may also be guilty of apathy in response to others who were victimised. See Surin 1986:120-121. 
directly or indirectly inflicted on them by other individuals or groups. This applies especially to the sins of the powerful, not because they are necessarily more sinful, but because their sins may have more devastating effects. Reinhold Niebuhr notes that while there is an equality of all human beings as sinners in the eyes of God, there is an inequality in terms of guilt. People are not always equally guilty of a specific act of wrongdoing in which they have been involved. ${ }^{29}$ This view of sin as being anti-social, as the destruction of human solidarity, the disruption of relationships between members of the extended family, is especially evident in African reinterpretations of $\sin ^{30}$

In a very tangible sense all HIV-positive persons may be regarded as victims of being sinned against. Those who carry the disease typically fear discovery, stigmatising, discrimination, rejection and abandonment. Indeed, it is "a shame disease, a cause for moral judgement and condemnation.." ${ }^{31}$ Due to the stigma around Aids, it may well be described as "the leprosy of our time." 32 Those who are employed risk joblessness through frequent sickness and prejudices related to various myths over the spreading of the disease. The disease evokes feelings of hopelessness, guilt (e.g. when mothers transmit the virus to their babies through pregnancy, birth or breast feeding), shame, loneliness, pain and anxiety over the progression of the infection and finally death. The family of the victims also suffer stigmatisation and economic hardship, especially if the affected person is the family's breadwinner.

In the context of the HIV/Aids pandemic there are also more explicit examples of victims who are being sinned-against. Here one may consider those who have contracted the virus as a result of rape, in the most horrendous cases through the rape of young girls and even babies. Less obvious but equally important examples are those women who have contracted the virus even though they have had only one sexual partner. Simply being married poses a major risk for women who have little control over abstinence or condom use in their own homes or their husband's sexual activities outside the home. ${ }^{33}$ Although guilt for marriage problems can seldom be put on one of the parties involved only, undisclosed sexual unfaithfulness in the context of the HIV/Aids pandemic amounts to assault. In addition, research indicates that many teenage girls experience their first sexual encounter as coercive and that attempts at refusal may have resulted in physical abuse, termination of a relationship or financial hardship. ${ }^{34}$ Indeed, HIV/Aids is a gendered pandemic that is greatly exacerbated by patriarchy. ${ }^{35}$

It is not clear whether babies who have contracted the virus from their mothers through birth may be regarded as cases of being sinned against. It would hardly be the sins of the mother that is at stake here. Although the father and sometimes the mother may be blamed in individual cases, the problem here is perhaps more of a societal nature. There is a failure of the current generation to provide a secure environment for the next generation to be born into. This is compounded by medical, financial,

Niebuhr 1941:233f.

30 See Maimela 1991, Pato 1997, Pobee 1979, Taylor 2001:123.

31 The essays in African women, HIV/Aids, and faith communities (Phiri, Haddad \& Masenya 2003) contain numerous horrendous stories of women who are victimised within the context of HIV/Aids.

32 See Saayman \& Kriel 1992. On the problem of stigma in relation to HIV/Aids, see Ackermann's theological reflections in this volume and also the work by Weinrich \& Benn (2004:46-49).

33 Vicci Tallis in "Aids is a crisis for women", Agenda 39, 1998, p. 9-10. Also quoted in Ackermann 2001:13. See also Rakoczy 2001.

34 See Ackermann 2001:14, Dube 2003:80-81.

35 Ackermann 2001, Dube 2003, Haddad 2002, Masenya 2003, Phiri 2003, Weinrich \& Benn 2004:26-31. 
economic and political factors which may have thwarted the availability of drugs and medical care that could have prevented mother to baby transmission. This leads us to another manifestation of suffering, namely as a result of what is often called structural violence.

e) The impact of structural violence may be even more serious than the direct impact of someone's sins on others. The contemporary theological tendency is to view the power of evil as the result of an accumulation, magnification and institutionalisation of collective human wrongdoing, of insensitive decisions, unsustainable habits, and dangerous practices. ${ }^{36}$ This leads to societal structures and behavioural patterns that are unjust because they are used to enforce domination, exploitation and alienation. Within these structures violence is practised not directly and personally, but indirectly through laws, customs and institutions. Through these behavioural patterns violence is often legitimised. ${ }^{37}$ Structural evil manifests itself - to name only a few obvious examples in the global problems of patriarchal oppression, economic exploitation and injustice, impoverishment, ethnic and religious conflict, a consumerist culture based on an instant gratification of desires and sexual entitlement, and environmental degradation. The point is clear: We live in a world deeply infested by evil. The concept of sin is certainly not outdated! Evil is clearly not a marginal phenomenon. If this were so, society might consider an expulsion of evil by isolating and eliminating the perpetrators. However, history provides us with ample examples indicating that the more radically this is done, the more dramatically evil may manifest itself in other forms, including in what is supposed to be good and in the apparatus set up to repress evil. It is therefore wise to reckon with a much wider compass of latent evil. ${ }^{38}$

As current debates on HIV/Aids indicate, the pandemic is closely intertwined with various manifestations of structural violence, political ideologies, global capitalism, the interests of pharmaceutical companies, consumerist behaviour, scientific disputes, etc. Millions of HIV-positive people have become victims of such processes that are far beyond their control and perhaps any individual's control. As Denise Ackermann observes, "Current global economic systems disrupt traditional societies, displace economic and educational infrastructures and the market demands of such systems and make access to prevention and treatment of disease difficult and expensive." ${ }^{39}$ Indeed, it is no coincidence that HIV/Aids is most prevalent in impoverished countries where people lack access to clean water, nutritious food, sanitation and basic health care. The poor are not only vulnerable to disease but often have to adopt survival strategies that expose them to health risks. ${ }^{40}$ The result is that the HIV/Aids pandemic has reinforced the prevailing stereotypes and suspicions about both Africa and the West. ${ }^{41}$

f) A final form of suffering is vicarious or sacrificial suffering, that is, suffering willingly taken up on behalf of others in order to alleviate their suffering. The history of the Christian tradition offers many moving examples of such suffering. Suffering can be a most creative and powerful social force when it is accepted within the context of resistance against violence in order to end violence and to liberate both the perpetrator

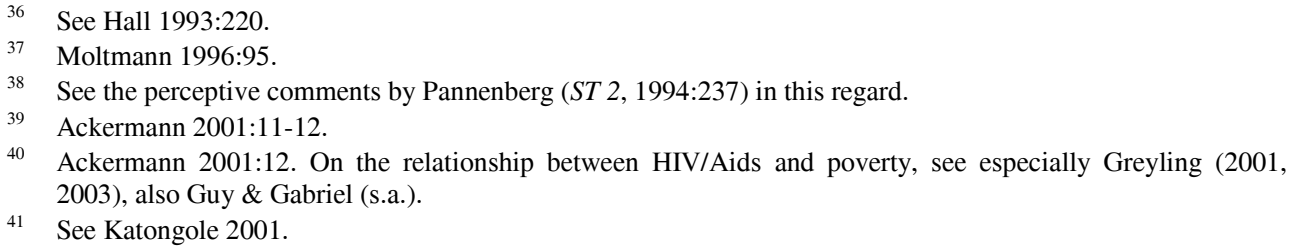


and the victims of such violence - as the examples of Mahatma Ghandi and Martin Luther King (jr) illustrate. The most obvious example is of course that of Jesus Christ who, according to the Nicene Creed suffered and died "for us as for our salvation."

This formulation calls for further theological explanation and interpretation since it is not immediately clear how the suffering that Jesus endured could alleviate our suffering. Moreover, as feminist theologians have rightly argued, calls for such sacrificial suffering are open to abuse and ideological distortion. The oppression of women has all too often been condoned with references to "taking up your cross", a denial of one's own interests, a willingness to serve others and to make sacrifices on behalf of others. In this way wives could be "kept at home" in order to "serve" their husbands and were expected to sacrifice their own careers in order to raise their children while the same was not expected from their husbands.

Notwithstanding this critique, it should be clear that the social and moral fabric of society would disintegrate without a widespread willingness of parents, educators, caregivers, nuns and priests to make such sacrifices over an extended period of time. In the past many young women spend the best years of their lives nursing their bed-ridden parents and in the process gave up prospects of furthering their own education or a married life. It would not be possible to respond appropriately to the HIV/Aids pandemic without the sacrifices of grandparents to look after their orphaned grandchildren, of spouses and neighbours to nurse those who are dying, of people who dedicate their lives to set up and manage Aids orphanages and other projects, and of activists who campaign for affordable medical treatment.

It should be clear from this analysis that a theological response to human suffering would be misguided if it fails to take the different sources of suffering into account. ${ }^{4}$ The tendency to reduce one form of suffering to another has to be resisted. All human suffering cannot be regarded as the product of moral evil - as Western Christianity has often failed to realise. Likewise, all moral evil cannot be regarded as the product of natural evil - as traditional religions in Africa have tended towards. ${ }^{43}$ At the same time, the various sources of suffering cannot always be neatly separated from one another. We may be both guilty and victimised at the same time. In the extreme case of suicide, death may be something natural, a form of self-destruction, the result of victimisation over a long period of time and related to structural violence, all at the same time. What is at least clear is that an assessment of particular experiences of human suffering calls for theological discernment.

This conclusion may easily be misunderstood as being judgemental: Once a selfappointed moralist can determine the source of suffering, a judgement can be pronounced on what God's response to the one who suffers may be. In response to such a moralising approach, there is an overwhelming emphasis in church discourse regarding HIV/Aids on avoiding a judgemental attitude and to focus on the needs of those who suffer from the pandemic. This emphasis should be affirmed since every person who suffers is indeed a victim and a fellow sinner who deserves the acceptance and assistance of those who can offer that. ${ }^{44}$ Nevertheless, to avoid any reference to the

42 It would, for example, be misguided to comfort a cancer patient with a reminder that Christ's suffering was more severe. See also Beker (1987) who calls for a distinction between various forms of suffering on the basis of an exegesis of Paul's writings.

43 See Bosch 1974:76.

44 Weinrich \& Benn $(2004: 48$, 53) suggest that concepts such as "Aids victims" should be avoided since they contribute to further stigmatisation. They argue that those infected by HIV are attributed a far greater burden 
impact of human sin can only lead to a shallow diagnosis of the pandemic and to superficial solutions. What theological discernment requires in this regard, is a recognition of the full complexity of human suffering. It may be pastorally necessary to judge the merits of each case, but such judgement will only be wise if it is not simplistic, if it takes the full spectrum of the sources of suffering into account and if it recognises the multiple connections between them.

\section{An Overview of Some Current Theodicies}

Where is God amidst the massive human suffering associated with the HIV/Aids pandemic? The analysis of the various sources of human suffering should indicate that a generalised response to this question could hardly be adequate. In this section I will offer a brief overview of some well-known approaches to theodicy. I will describe each position briefly, note how the particular approach steer between the various polar opposites identified above and investigate how the HIV/Aids pandemic may be addressed in terms of the approach. In the next section I will then come back more specifically to the question as to where God is amidst the pandemic.

a) "Suffering is incomprehensible. We simply have to accept it as something that comes from God's hand. God's ways are wonderful and in our own best interests but they are sometimes hidden for us. A well-known Christian chorus calls us to "Be still and know that I am God." A sense of humility is called for because we are not God; our understanding remains very limited. Like Job we have to confess that we do not know why there is so much suffering and why it is so unevenly distributed. The most appropriate response for human beings is to live a quiet life in gratitude before God (coram Deo)."

Indeed, silence may be a far more appropriate response to the enormity of suffering than feeble and often insensitive attempts to provide explanations for suffering. ${ }^{45}$ In this quietist approach to the theodicy problem human responsibility to address the sources of suffering is underplayed. God is the potter and we are the clay. Silence in the face of suffering is regarded as more appropriate than an anxious search for sophisticated answers. God's power to address the human predicament is maintained even when this is not demonstrated. Such an approach may encourage an unchallenged acceptance of all suffering and suppress a resistance against suffering. ${ }^{46}$

Such an approach to the HIV/Aids pandemic may lead people to accept that millions of people may well die as a result of the pandemic. Maybe God has a higher plan in this regard? This need not prevent people from working towards a cure for the disease; this will be found if this is God's will. However, it is stressed that an over-anxious activist

of guilt for the infection / illness than in the case of other diseases such as malaria: "One normally does not condemn people for having failed to sleep under a mosquito net and therefore contracting malaria. In the latter case, one proceeds to investigate the social and psychological conditions of mosquito net usage, and not to stigmatize those who fell sick with malaria for their disease" (Weinrich \& Benn 2004:48). In this way the equation of HIV-infection with immoral sexual behaviour may be resisted. This position certainly helps to challenge a narrow and selective morality and may well help to reduce stigmatisation. However, in my view, it is more helpful to acknowledge, and not to minimise, the devastating role played by human sin within the context of HIV/Aids. To treat HIV/Aids as a disease without reference to morality and sexuality is to operate with a reductionist analysis. In addition, it may be more helpful to view human sexuality (in the private sphere) as an analytical tool to investigate public morality. Morality cannot be reduced to matters of sexuality, but the sins of society (for example domination in the name of gender differences) are better manifested in human sexuality than in most other spheres.

45 See Maluleke (2001:132) on the ambiguity of the silence of the churches on HIV/Aids.

46 See Migliore 1991:106. 
campaign on Aids issues cannot and does not come to terms with the reality of death and the prevalence of similar catastrophes throughout history.

b) "We need to offer our protest before God about such suffering. We cannot accept human suffering as being God's will. God's will is not hidden or mysterious but known in the Torah and in the teaching of Jesus and Paul. It is unacceptable and indeed incomprehensible that God could allow such suffering to continue. A radical trust in both God's power and God's love calls for a complaint to God in God's name against God's refusal to act. ${ }^{47}$ This may be expressed in the form of a prayer and the hope that God will still act to alleviate the suffering. It may also be expressed, perhaps more authentically, in the form of lament." ${ }^{, 48}$

The emphasis in this approach is again on God's own responsibility and not only on human responsibility. The origins of evil and suffering are not found in something outside God's power and God is therefore called to account for such evil. Unlike the previous approach, suffering is not mystified. It may be comprehensible but God's refusal to act is not. Also note that God's power and God's love is neatly balanced in this approach.

In such a response to HIV/Aids the stakes would be raised considerably. The disease should be confronted and eradicated. While this may serve as a radical source of inspiration to fight the disease, it remains unclear how God is expected to bring about an end to suffering. This may leave many exhausted and disillusioned wherever and whenever the disease triumphs in particular cases.

c) "Human suffering is the product of human sin and may even be regarded as God's punishment or chastisement for sin. God is not responsible for human suffering because God willed the emergence of free, rational but therefore also fallible creatures. The possibility of sin and of suffering is a necessary function of human freedom., ${ }^{49}$

47 See the many biblical expressions of such protest to God against God. Psalm 22:2-3 reads: "My God, my God why have you abandoned me? Why did you not come to my rescue? Why do you not listen to my mourning? My God, I call on you throughout the day and the night but you failed to answer me ..." (my free translation). See also the powerful prayer of protest in a letter by Jessel Rakover, a Polish Jew, found in the Warschau ghetto shortly after World War II: "I believe in You, God of Israel, even though You have done everything You could to discourage my faith in You. I believe in Your laws, even though I cannot condone your governance ... I bow my head before Your greatness, but I will not kiss the whip with which you have beaten me ... We have a right to know, we who are tortured, humiliated, buried alive, burnt alive, insulted, ridiculed, murdered by the millions: How long are You going to allow this to happen? ... I say this because I believe in You, more than ever before, because I am now certain that you are my God, because You cannot be the God of those whose horrific deeds cannot but be an expression of their godlessness. I die in peace but not appeased, persecuted but not enslaved, embittered but not cynical, a believer but not a beggar; a man who loves God but who does not say 'Amen' do everything that God does. I have followed God even though He has discarded me. I obeyed his commandments even when He thrashed me for it. ... These are my last words to You, my infuriated God: This will not help you at all. You have done everything to put my faith in You to shame, but I will die just as I have lived, praying to You: Hear of Israel, the Lord is our God, the one and only God. In Your hands, oh God, I commit my spirit!" (My translation of this remarkable prayer as quoted in Bosch 1974:88 in Dutch and with reference to the book Leve de Kerk by H. Jonker, Nijkerk: Callenbach, 1969, p. 147-8).

48 See the helpful contributions by Ackermann (e.g. 1996, 2001) on lament. Lament is a form of mourning but can also include a form of subversive protest and the expression of the hope for healing. It is a refusal to accept the way things are: "Lament is never an end in itself. It is undergirded by the hope that God not only can but that God will hear the cries of the suffering and the penitent and will act with mercy and compassion" (Ackermann 2001:26). Lament is therefore the opposite of mute suffering, a suffering that cannot be brought to expression and therefore cannot be eliminated (Dorothy Sölle).

49 It should be noted that suffering as a result of one's own sins cannot be equated with punishment for such sins. In this sense we may at times be responsible for our own suffering; God cannot be held responsible for 
This Augustinian approach to suffering refuses to put the blame for suffering on God or God's good creation (e.g. sexual instincts) or any force beyond God's control (fate). It accepts human responsibility for sin as the most obvious cause of human suffering. Whatever form of natural suffering there may have been, this is far exceeded by the devastating consequences of human sin (evil). Any refusal to accept human responsibility, directly or indirectly, could only obscure the underlying human predicament and will encourage a trust in pseudo-solutions and surrogate gospels.

This approach tends to emphasise God's righteousness and power more than God's love. The emphasis is on human responsibility and the incomprehensibility of the emergence of sin (it is not God's fault). The most appropriate response is a confession of $\sin$ and the proclamation of God's forgiveness. However, such a confession would not resolve several theological problems that follow from this position. Why did God allow sin to emerge in the first place? What about those who suffer as a result of the sins of others? Would this not blame victims (e.g. victims of rape) for their own suffering? Why does God need to punish us that much? Did Jesus not teach explicitly that there is no direct correlation between sin and suffering $?^{50}$ It would clearly be improper to ascribe guilt to the victims of natural suffering or human injustice.

There are numerous caricatures of this position amongst theological responses to HIV/Aids. The most notorious one is that Aids is God's punishment for homosexuality and sexual promiscuity. Such caricatures should not hide the devastating impact of human evil in both the spreading and in the response to the pandemic.

d) "God is teaching us a lesson through suffering. Suffering comes from God as a form of 'divine pedagogy' (John Hick). It strengthens our character (Irenaeus). Something good may come out of suffering. The creative acceptance of suffering provides an opportunity for spiritual growth. The whole creation is a 'vast teaching machine' with moral lessons to be found everywhere."

our suffering. See Nicolson 1995:25-32, Slattery 2002:25-26. Nicolson (1995:32) stresses that even for those who have been promiscuous and whose sickness is therefore to an extent the consequence of their own actions, the message of the church should be one of compassion and forgiveness, of love and acceptance - not of God as the judge over sin.

This leaves the question whether God would never punish sin - which would be contrary to many texts in the Old Testament. The theological tendency, especially in a time of HIV/Aids, is to emphasise that any notion of punishment should indicate how such punishment could be a function of God's love for the wrongdoer. By contrast, earlier notions of punishment also allowed for the need to exorcise evil from society. The Babylonian exile, under which all citizens - the faithful and the apostate - suffered, was regarded by the Old Testament prophets as God's way to eradicate evil and to provide a new beginning for Israel under God's Law (which, as history demonstrates, was not successful either). Perhaps we should admit that a God who could allow the destruction of Jerusalem is even less palatable today than it was then. Although it would not help theologians to shy away from such difficult problems, it seems clear that the main pastoral challenge is to counter the perception that there is a direct correlation between a particular person's HIV-status and God's punishment. That would ignore the many victims of structural evil and more direct forms of being sinned against (see $3 \mathrm{~d} \&$ e above). See also the note below.

50 See the example in John 9:1-3: The blind man was not born blind on account of his own sins or the sins of his parents. In the context of structural evil there may be a general correlation between sin and suffering but no direct correlation between sin and suffering can be derived from that in particular cases (Bosch 1974:81). Jesus broke the bond between sin and suffering since he who was without sin suffered even more than sinners (see Gennrich 2004:41).

51 See Bosch 1974:79, with reference to FM Young's assessment of Basil the Great's approach to the theodicy problem. The most notorious example of this approach may be found in the "comfort" offered to parents whose young child has died: "God picks he most beautiful roses for his garden." or "God is showing you that he loves your child more than you loved Him." Or "It is an indication of God's trust in you that he requires from you to cope with such heavy burden." See Bosch 1974:80. 
The attractiveness of this approach is related to its emphasis on human freedom and responsibility. The question would remain though whether that much suffering is really necessary to teach us a lesson? Are some forms of suffering not in the end destructive of character? Is the emphasis here not on God's power more than on God's love? Is this approach not more concerned with protecting God's honour through logical argumentation than with addressing the anguish of those who suffer?

From a point of departure in this position the HIV/Aids pandemic may well be regard as a moral challenge. It serves as an opportunity for moral regeneration and for reflection on the task of moral formation. More specifically, it serves as a warning against sexual promiscuity. ${ }^{52}$ It may well encourage something like an ABC strategy where the virtue of faithfulness to one's sexual partner is extolled. Presumably, an inability to grasp the opportunity for the formation of character leaves us with the use of condoms $^{53}$ as the only viable alternative for those who are considered by ecclesial authorities and moralists to be moral failures. ${ }^{54}$

52 Weinrich \& Benn (2004:49) suggest that the moral issues around extramarital sexual intercourse should be distinguished from moral issues around HIV/Aids. The comment that HIV infection is not caused by having multiple sexual partners but through the transmission of a virus from one person to another. It is the risk of infection that is increased through multiple sexual partners.

53 See the perceptive comments on the use of condoms as a strategy to address HIV/Aids by Denis (2003), Nicolson (1995:50-54), Saayman \& Kriel (1992:54-69), Slattery (2002:55-58) and Weinrich \& Benn (2004:63-66). It seems to me that confusion in this debate results from a failure to distinguish between the morality that may be promoted within Christian communities (sexual fulfillment within long-term relations built upon mutual respect and reciprocity) and the measures that the church may promote in the wider society (where the use of condoms is an important alternative to death). In the wider society, the church may nevertheless have to note that the "gospel" of salvation through condom use has several limitations. It may well encourage further promiscuity, it is a technical, mechanistic response to a health problem that may not appeal to African societies, there are logistical problems to deliver condoms to rural areas, the cultural resistance against condom usage remains an immense inhibiting factor, condoms are seldom used consistently and correctly over long periods of time and they may break. Clearly, the use of condoms may help to reduce HIVinfection statistically, but will not be sufficient on its own to prevent the spread of the disease. To encourage the use of condoms as a form of pastoral advice would clearly not be sufficient.

54 See Pillay 2003:116. Denis (2003:74) notes that the emphasis in the ABC-strategy on abstinence and fidelity does not take the pervasiveness of violence against women, the legacy of migrant labour and the disruption of family structures into account. It is also dangerous because it unintentionally encourages exclusion. Because of the moralistic tone this strategy contributes to the conspiracy of silence which surrounds sexuality in South Africa. See also Greyling 2001, Kanyoro 2002 and Qakisa 2002. At the same time, the success of this strategy in countries such as Uganda can scarcely be overlooked (see Green 2003).

In an essay on sexual illiteracy Rosemary Ruether (2003) recalls a conversation with Ephraim Mosothoane, a professor at the University of Transkei, in which Mosothoane described how local Africans had traditionally managed young people's sexual development and how Christian missionaries had then sabotaged a perfectly functioning system. He described how Xhosa initiation schools traditionally included two aspects of moral instruction on sex (for boys and girls): 1) How one can provide sexual pleasure for one's partner; and 2) How one can avoid pregnancy. After a period of free but supervised sexual experimentation, the young people married and were then expected to be faithful to one partner. On this basis they could go into marriage experienced in how to give one another pleasure and equipped to elect or avoid pregnancy Ruether (2003) comments: "When the missionaries came, they were horrified at this practice, seeing it as sexual license, and demanded that it be stopped. The missionaries sought to teach the local Africans their own values of sexual abstinence before marriage. The result was a disaster with premarital pregnancies happening for the first time. Young people didn't stop sexual experimentation before marriage, but they now did so clandestinely, without learning how to avoid unwanted pregnancies."

Such instruction seems to assume sexual activity at a young age. It does not commend the high virtue of abstinence before marriage of traditional Christian instruction. With a few qualifications it may, in my opinion, nevertheless be more virtuous, appropriate and realistic than the ABC-strategy to address the spread of HIV/Aids. The qualifications are: 1) Both aspects should include but not be reduced to technical instruction. 2) The techniques should include ways of avoiding HIV/Aids and not only pregnancy and 
e) "God's power is a function of God's persuasive love. God's love is vulnerable. ${ }^{55}$ God's power is the strange power of the cross. This is the way in which God opted to address suffering; not through coercive (or even violent) control that would perpetuate suffering, but through a kenotic surrendering of God's power, through compassionate solidarity in suffering, through patient and vicarious suffering that would identify, expose and transform the sources of suffering from within. God's love for creation implies a vulnerability that causes God grief and suffering when this love is rejected or not reciprocated. There is a close correlation between intimacy and vulnerability, also for a God of love."

This approach offers an explanation for human suffering by emphasising the limitations of God's power. It suggests that human suffering is to some extent inevitable. Pain is a necessary function of creaturely existence and of human finitude. To be finite is to be different from the infinite God; such finitude implies various human limitations and human suffering follows from such limitations. God's creation is good, not perfect. God's act of creation also implies self-restriction. With the very act of creation God opted to allow creation a life of its own. God's love allows us the space to take our own decisions. God does not violate the integrity of creation by intervening in and disrupting the laws of nature. For that reason God also allows human sin to emerge within God's good creation even though human sin aggravated human suffering immensely. ${ }^{56}$ There is an intrinsic connection between love, vulnerability and suffering. Conversely, an attempt to avoid suffering at all costs can only lead to a suppression of love. ${ }^{57}$ The ideal of a life without suffering leads to consumerist apathy, the spiritual sickness of contemporary Western societies. Apathy is the opposite of love since loves longs for affection, to be affected. ${ }^{58}$

The intuition behind this approach to the theodicy problem is that God's love should be central in any theological attempt to address human suffering. It does offer a fairly elaborate resolution for the tension between God's love and power by regarding God's power as a function of God's love. God's power is not coercive but persuasive. The

sexually transmitted diseases. 3) Sexuality should not be reduced to sexual intercourse but should include all aspects of intimacy (starting with body language, visual contact and hugs) and would not necessarily include sexual intercourse itself. In fact, especially for young teenagers, it would normally not include sexual intercourse. 4) For boys, a crucial part of the instruction should be to focus not on their own sexual pleasure but on that of their partners. This cannot be done without respect for the partner. I would presume that, especially for girls, sexual fulfilment is seldom experienced outside a long-term, steady relationship that provides security (in the case of pregnancy) and is based on mutual respect and reciprocity. If boys could be taught such respect, this would indeed make a huge difference. Moral instruction in a Christian context could radicalise such respect on the basis of biblical examples (including examples from the ministry of Jesus) showing what such respect implies but also what the consequences of disrespect may be. 5) The instruction could include rituals amongst males and females that may be followed where cases of such disrespect become evident. 6) In order to allow openness and critical dialogue, such instruction should not necessarily be provided by instructors of the same gender only.

55 See Hendrikus Berkhof's emphasis on God's “weerloze overmacht” (Berkhof 1985:136-142).

56 Van de Beek (1984:147-165) mentions several arguments which may be raised against the notion that God is not responsible for sin and evil, could have prevented it, but within God's providential governance opted to passively allow evil: 1) Why did God create beings that could sin in the first place? Does this not make God ultimately responsible for sin? 2) Can God be passive in anything that God does? 3) A person who could have prevented an accident but passively allowed it to occur would nevertheless be held legally accountable. 4) There are examples in the Bible where God did not allow someone to sin (e.g. Gen 20:6). Why, then, does God not prevent sin and evil always? Is the image of a God who allows Satan to cause Job immense suffering after a heavenly bet not morally repulsive?

57 See Richard 1992:44, with reference to insights derived from Jürgen Moltmann.

58 See Richard 1992:77, with reference to insights derived from Dorothy Sölle. 
imperative of human responsibility would follow from the indicative of what God has done in Jesus Christ.

This position remains vulnerable in the face of the feminist critique against the abuse of sacrificial suffering to legitimise the oppression of women. If suffering is a function of powerlessness, such powerlessness should be resisted not glorified. The conditions within which people are forced to suffer should be abolished. The focus on the power of the cross also begs theological questions about the power of the resurrection. ${ }^{59}$ If God has the power to raise Jesus from the dead within the context of human history, why does God not address other forms of human suffering too?

This position may encourage a profound solidarity with the many victims of the HIV/Aids pandemic. If God cannot and will not prevent human suffering, it does provide some solace to the victims to realise that God is present in Jesus Christ in the midst of their suffering. In a world where those who are HIV/Aids-positive are stigmatised and cast aside, only a crucified God (Moltmann), one who has been despised and rejected by society, can be liberating.

f) According to some expressions of liberation theology, suffering is quite comprehensible. It can be attributed to the forces of evil. God is against such evil. We as human beings are God's instruments who are called to resist such suffering. This requires from us the courage to resist evil. What is required is not the passive acquiescence in suffering but courageous human participation in God's struggle against suffering. ${ }^{60}$

Hope in the promises of God may encourage us to fight against the causes of the HIV/Aids pandemic, to care for its many victims and to work for a better a future. Like protest theodicies it analyses and resists evil, but unlike protest theodicies the emphasis here is on human responsibility and not so much on God's responsibility. The danger here is that God-talk may become little more than a metaphoric way of talking about human responsibility. It also remains a question whether such a futurist orientation can bring salvation also for the victims of the past. Has God sacrificed the dead for the sake of the living, the past for the sake of the future? And will a better society finally arrive somewhere in the future or will new manifestations of evil surface in each new dispensation?

\section{Where is God Amidst Human Suffering?}

Where on earth is God? Is God not aware of all the suffering related to the HIV/Aids pandemic? What is God doing while millions of people are suffering and dying? Or is God perhaps unconcerned, absent or non-existent? Why does God not bring an end to all the suffering?

On the basis of the above overview of various approaches to the theodicy problem, I will investigate in this final section a number of possible responses to these questions critically. Although the drift of the discussion will soon become clear, I will refrain from suggesting a particular answer to this question and will also attend to some inadequate

59 See the comment by Richard (1992:34) with reference to the work of Edward Schillebeeckx: "(W)e are not redeemed by Jesus' death - how could an event so shameful and negative be 'redeeming' in any sense? - but is redeemed despite it, a 'despite' that God transcends by his unconditional victory over the negative and destructive aspects of history."

60 See also Migliore 1991:114. 
responses. In the process, I will also describe some of the major challenges posed by HIV/Aids to the Christian faith and to Christian theology.

a) "We need to address the HIV/Aids pandemic as if God is not there. We need to tackle the problem ourselves and accept full responsibility in this regard. God is not going to help us by any interventions from above."

From his cell in the Tegel prison, Dietrich Bonhoeffer famously concluded that the history of modernity has reached a point where "God as working hypothesis" is no longer required - especially not as a necessary hypothesis to carry out human responsibilities in the fields of science, politics, finance, medicine or morality. What is required, instead, is the sober recognition that we must live in the world as mature men and women, etsi deus non daretur, as though God is not given. We have to live a life of prayer and discipline before God as if we are living without God. We have to accept responsibility for what we do and for what we leave undone. For Bonhoeffer, this recognition was not a concession to the godlessness of the world, but a form of faithfulness to a life under the cross. The challenge posed by HIV/Aids to Christian faith today is to explain to a world infected by HIV/Aids what difference, if any, it makes to believe in God, that is, the God of Jesus Christ.

b) "God is not far from us but is present in God's own creation. ${ }^{61}$ This is evident from the incarnation of Jesus Christ and the presence of God's Spirit, the 'Giver of Life' (Nicene creed). Our bodies are the 'temples of the Holy Spirit.' In fact, the world may be regarded as God's body. ${ }^{62}$ If so, God's own body has Aids. Human suffering from HIV/Aids is therefore closer to God than we can ever imagine."

This position is clearly attractive because it demonstrates God's solidarity in human suffering in a vivid and tangible way. Its emphasis on embodiment is also crucial. As Denise Ackermann observes, bodies - sick, maltreated, abused, poor, vilified bodies, all too often the bodies of women and children - are at the centre of the pandemic. To address the pandemic, embodied acts of care, comfort, support and acceptance are needed. A panentheist emphasis on God's immanence does raise questions about God's transcendence though. This is crucial precisely for the sake of overcoming the pandemic. The question is whether a God who only suffers with us can really help us in this regard. The challenge to Christian theology is therefore to give a plausible account of God's transcendence and to do in such a way that it will have a healing, liberative and salvific thrust.

c) "A deadly virus such as the HI-virus is one of God's ways of population control. This may be hard message for us to swallow, but the alternative is vast human overpopulation that will lead to even more human misery. Indeed, viruses form part of God's good creation and may be regarded, from a larger perspective, as an expression of God's providence in history."

This position has rightly been criticised as exceptionally harsh. It is clearly stronger on God's power than on God's love. As Ron Nicolson observes, "It reduces God to something like an impersonal bureaucrat who is more concerned for social engineering than for personal suffering. ${ }^{, 63}$ It also fails to see that environmental exploitation is as much a function of consumerist over-consumption as of population growth. In any case,

61 See the title of Moltmann's work God in creation (1985)

62 See especially McFague 1993 and the reflections on HIV/Aids and embodiment by Ackermann 2001:20-22 and Fröchtling (2002).

63 Nicolson 1995:34 
even an immense tragedy constituted by 10 million Aids-related deaths per year will slow down but will not resolve the global population increase of more than 80 million persons per year.

Nevertheless, this position at least maintains a form of realism which resists a denial of the problem of population / consumption, a denial of the immense suffering related to the processes of natural selection and of the cataclysmic forces that epitomises planetary and cosmic processes. It also refuses to let God off the hook. Sharply formulated, if God created a world with deadly viruses such as HIV, should God be exempted all too easily from the responsibility for millions of people who are dying from Aids related diseases? How dare God declare a creation in which such viruses thrive to be good? Clearly, Christians are called to account for their belief in a loving Creator, in the "Giver of Life" and in God's providence and sustenance in history. Moreover, those of us who wish to the resist the position described above are challenged to find less draconian ways to curb the environmental impact of the current human population and consumption.

d) "HIV/Aids may be seen as God's punishment for human sin and more specifically for homosexuality and sexual promiscuity. The answer to the question as to where God is in the midst of this pandemic can only be answered adequately with reference to God's judgement over the legacy of human sin."

Again, this position is excessively crude and harsh. As it was argued above, this position is stronger on God's power than on God's love. It is unsophisticated in that it does not differentiate between sinners and their victims - those who are "sinnedagainst." The generalised teaching of the church that we are all sinners and that what happens to us may be regarded as God's punishment for our sins has had devastating consequences - especially for women and children who are victimised in the context of HIV/Aids. $^{64}$

Yet, a denial of the impact of human sin on the HIV/Aids pandemic could only lead to a shallow theological diagnosis of the scope and the depth of this predicament. There is a crucial fallacy in many Aids-awareness campaigns that the major problem is one of ignorance and that conveying the correct information about the pandemic would result in appropriate action. ${ }^{65}$ In fact, such information (and alarming Aids-statistics) may only breed despair. Then death by Aids may just as well be regarded as an inevitable fate: "If I shall die young, I might as well enjoy life and sleep around as much as I want!"66 By contrast, the Augustinian and Lutheran traditions of Christianity have maintained that the human predicament is far, far more serious than a lack of knowledge. The challenge to Christian faith and Christian theology is to explain that God's judgement over sin is indeed good news. The many victims of the pandemic are crying out for a just verdict. The message of the gospel is that this verdict may also harbour a gracious word of forgiveness for sinners and, as a result, the possibility of reconciliation between God, sinners and their victims.

e) "God is present amidst the HIV/Aids pandemic by being with those who are suffering. The symbol of the cross reminds Christians that God acted in Jesus Christ to show

64 See Musa Dube's account of the impact of HIV/Aids on children in Botswana (Dube 2002). See also Kanyoro 2002, Weinrich \& Benn 2004:32-36.

65 See also Maluleke 2001:136. Greyling (2003:130) also observes that "people in South Africa have a good knowledge of HIV/Aids, its mode of transmission, and how it can be prevented but often fail to act on this."

66 See Katongole 2001:156. 
God's compassion for those who are suffering, to demonstrate fellowship with those who are stigmatised and to resist evil in solidarity with the victims of such evil. This inspires Christians to act with compassion, kindness, humility and gentleness to assist those of suffering, to weep with those who are weeping."

In his book Night Elie Wiesel tells a story of an incident in Auschwitz where a young boy was hanged together with two adults before all the prisoners for a minor infringement of the camp's rules. The boy did not die immediately since his body was so light. He hanged on the gallows for more than half an hour, struggling between life and death, dying in slow agony. As he hanged on the rope someone asked, "Where is God now?" A voice within Wiesel responded: "Where is God? Here He is - He is hanging here on this gallows." ${ }^{67}$ This incident illustrates the power of solidarity in suffering under extreme affliction. As Bonhoeffer commented from prison: "The Bible directs us to God's powerlessness and suffering; only the suffering God can help."68 There is certainly something much more attractive in this position than in some of the previous ones. It focuses on God's compassion and vulnerability instead of God's majesty and almighty power. It provides comfort to those who feel abandoned by everyone and by God in their suffering. The question, though, is whether such vicarious suffering can indeed be redemptive. If not, it should preferably be avoided. Theologically, this will only be possible if justice can be done to the dialectic between cross and resurrection (a theme which is, despite the apostle Paul's assessment in 1 Corinthians 15:14, often less central for Christians than the cross). The crucial challenge for Christians living with HIV/Aids is to demonstrate the strange power of the message of the cross. The temptation will always be to amend or substitute this message with something easier, more manageable or more palatable.

f) "HIV/Aids is a disease that is symptomatic of our society. The Christian message of salvation includes a ministry of faith healing for those who are sick. Even though there is said to be no cure for Aids, God's mercy can conquer any disease and even death itself."

For some Pentecostal churches, HIV/Aids may be somewhat of an embarrassment precisely because there is no known cure for the disease. ${ }^{69}$ This poses an obstacle for a ministry of faith healing. When a person's faith is put to the test through such a ministry and healing does not take place, this may, of course, lead to disillusionment. Some may opt to avoid any talk about a ministry of healing altogether. However, this would leave the challenge for Christians to explain what significance the message of salvation could have within the destructive realities of the HIV/Aids pandemic. Indeed, the societies in which we live cry out for deliverance. How, then, can the salvific work of the Holy Spirit be proclaimed in the midst of a society infected by HIV/Aids? Where can a com-

67 See Migliore 1991:103 for one reference to this well-known story. Johann Baptist Metz warns that this story should not be identified with Christ too easily within a Christian context. "Only he (Wiesel), I think, can alone speak of a God 'on the gallows' not we Christians outside of Auschwitz who sent the Jew into such a situation of despair or at least left him in it." Quoted in Surin 1986:124. To speak of the cross as a place where a compassionate God is present may be another way to make something that is inherently violent more attractive (Van de Beek 1986:113).

68 See Letters and papers from prison (New York: Macmillan, 1972) p. 361. Also quoted in this context by Migliore 1991:115. The theme of the suffering God is taken up especially in the oeuvre of Jürgen Moltmann.

69 See the Masters thesis by Chris Isaacs (1998) in this regard. See also Gennrich 2004:53 and the essay by Kealotswe (2001) on healing practices among AICs in Botswana. Kealotswe concludes that AICs, through their diagelos (clinics) do not provide a cure for HIV, but that they do offer psychological healing, better treatment (compared to hospitals or home-based care) for minor diseases, and as a result an extension of the lifespan of HIV-positive persons. 
prehensive notion of healing be found that would attend to the medical, psychological, social, ecological and spiritual dimensions of health and healing? For churches not to respond to an issue of such magnitude would indicate that the gospel is irrelevant and offers no saving grace. ${ }^{70}$ It would allow secular but shallow notions of redemption, for example redemption through hedonism and instant gratification, to flourish. ${ }^{71}$ By contrast, many church leaders are rightly seeing the HIV/Aids pandemic as an urgent call to realise the need for spiritual and societal transformation and to pray for the healing of both church and society.

g) "Some churches have acknowledged that HIV/Aids is affecting the life of the church in the most intimate way, for example by admitting that 'Our church has Aids!' On the basis of this admission, the church may provide a fellowship (koinonia) where those who are stigmatised as being HIV-positive can receive acceptance amongst fellow sinners who feel free to confess their sins and have received God's forgiveness. ${ }^{72}$ Moreover, the body of Christ is a loving community where people care for one another and serve one another's needs in whatever ways this may be required within the context of HIV/Aids. The various ministries of the church may also be extended to those outside the faith community in order to address their needs. The clearest way in which God's presence may be discerned in a world infected by HIV/Aids is in and through the ministries of the body of Christ."

There is clearly much that is attractive in such a vision of God's presence in the church. The challenge for churches will be to concretise such a vision in order to be credible witnesses to the gospel. Unfortunately, there are indications that the church lags behind other organisations in this regard in terms of attitudes and a mobilisation of resources. ${ }^{73}$ The Treatment Action Campaign has done far more than most Christian organisations to address the needs of those who are in need of medical treatment. Church leaders have contributed to the stigmatising of those who are HIV-positive. HIV-statistics amongst those with a high attendance of church activities are not necessarily different from other sections of the population. ${ }^{74}$ Nevertheless, the significance of moral formation, the formation of character and moral communities in the fight against HIV/Aids should not be underestimated. ${ }^{75}$ During a visit to Malawi in 1997 I was informed that the HIV/Aids-infection in some rural communities was as low as $1 \%$ while it was far higher in others. The difference was ascribed to the moral leadership of village chiefs. If this is the case, local Christian communities in South

70 See Gennrich 2004:43, Nicholson 1996.

71 De Gruchy 2000:19-20.

72 Greyling (2003:133) mentions that ten minutes of each service in a congregation in Gugulethu is dedicated to people sharing their pain, fears and joys of living with HIV. At first, the majority of the people who shared their stories were not members of the congregation. Initially there was little response, but gradually people started coming forward to share their pain since they lost their fear of disclosing their infected status. If Christians can confess being infected by sin on a weekly basis there should be room in a community of forgiven sinners for those who are infected by the HI-virus to disclose their status.

73 For empirical evidence regarding attitudes of church members towards HIV-infection, see the work of Van der Ven, Dreyer and Pieterse (2003). It is clear from such evidence that church affiliation does not significantly affect attitudes towards and a stigmatisation of HIV/Aids victims.

74 This comment is based on an observation made by Rev Christo Greyling during a conference on "The church and HIV/Aids" at the University of the Western Cape, June 2001. See also Greyling 2001.

75 See Larry's Rasmussen perceptive study on Moral fragments and moral community (1993) and Denise Ackermann's (2001:22-25) emphasis that ethical codes and moral discourse on HIV/Aids prevention can only be meaningful within the context of moral communities built upon respect, mutuality and reciprocity. See also Weinrich \& Benn 2004:102-4. 
Africa can potentially play a crucial role to prevent the further spread of the disease through behavioural change (if necessary conversion) - which is close to the heart of the gospel. ${ }^{76}$ Indeed, becoming an Aids-statistic is not a fate that cannot be prevented.

h) "God's presence on earth becomes visible and tangible especially through participation in the Christian liturgy, including worship and the celebration of the sacraments. Through Christian worship we learn to see the world through God's eyes - with compassion. This affects the life and ministry of Christians in society. Through the water of baptism, the stigma of $\sin$ in its multiple manifestations is symbolically cleansed. This initiation ceremony indicates that all the members of a Christian community can only understand themselves as stigmatised sinners who have been forgiven. Through participation in the Holy Communion the Christian community is nourished by keeping the "dangerous memory" of Jesus Christ alive. For a church 'which has Aids' such nourishment is a sign of God's grace, a 'strengthening of its immune system' in order to face the always imminent threat of the terminal phase of the disease."

There is clearly much that can be appreciated in this position too. Participation in the sacraments cannot be an exercise in moral gatekeeping - as both baptism and the Holy Communion has often become in local parishes. The sacraments are there to nourish forgiven sinners and certainly not to exclude sinners. The challenge for Christian communities will be to explore creative possibilities to celebrate the liturgy and the sacraments in such a way that the church is strengthened in its faith and that the significance of the whole liturgy for an HIV/Aids infected society would be evident. ${ }^{77}$

i) "In a world where millions are people are dying from Aids-related diseases, most often prematurely as young adults, Christians should be bold enough to articulate their hope in the resurrection of the dead anew, the hope to remain in the presence of a God who transcends life and death itself. God's presence amongst those who are suffering and dying from Aids-related diseases is something that can only be discerned eschatologically. This will be evident through God's final, just and merciful judgement on sin that will bring justice to the victims of HIV/Aids and in God's eternal faithfulness to the works of God's own hands."

I have argued elsewhere that the Christian hope for the resurrection of the dead is essentially a hope in Godself. ${ }^{78}$ It is born from the complex and pluralistic witnesses in the Judaeo-Christian tradition to the promises and the everlasting faithfulness of the living and eternal God. It is an extrapolation and radicalisation of a trust in God the Creator who transcends human and cosmic finitude and who maintains an unconditionally creative relationship with the created order. Indeed, "Resurrection hope is radical faith in the God who remains faithful to his material and mortal creation, valuing it too much to let it perish." ${ }^{, 79}$ More specifically, it is a confirmation of the Christian belief in Jesus Christ, the Risen One. It expresses the Christian hope in the power of the Spirit who makes all things new. This comes to fruition in the hope that in death we will meet not nothingness but Someone: the God of grace who raised Jesus Christ from death. Christian hope does not only refer to the presence of the suffering God amidst human suffering; it hopes for divine judgement that would provide justice for the

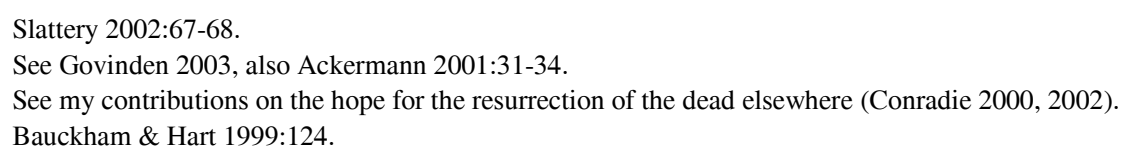


victims of the past and for an eschatological victory of divine love over all evil and the participation of the suffering creation in God's eternal joy.

In a context where millions are dying from Aids-related disease it may offer comfort to the dying to hope that every life lived will remain before and with God forever. For God, nothing that has happened in history has been lost. Our lives, our pain, the injustices that we suffered, our moments of joy are kept, judged and healed in the presence of God. The challenge for Christian theology in a world where millions are dying is "to give an account of the hope that lives in us" (1 Peter 3:15) - if indeed this hope may be found to be still alive.

\section{Conclusion}

It should be clear from the discussion above that amongst the many challenges that HIV/Aids pose to Christian communities there is one that cannot be neglected: To offer a plausible account of each aspect of the Christian faith. The task of Christian theology is to assist Christian communities in this task. The pandemic requires from us nothing less than a revision of the entire Christian dogmatics. ${ }^{80}$ This can only be done if the various aspects of Christian faith can be integrated within the single narrative of God's love for creation. The task of Christian theology may be described as re-telling, retrieving and re-interpreting the story of God's creative, nourishing, hurt, enduring, salvific, innovating and consummating love for that which God has brought to life. In order to address the suffering related to the HIV/Aids pandemic we need to locate our lives within this story - God's story. ${ }^{81}$

80 See also Hall's discussion in God \& human suffering (1986) where he discusses he themes of creation, fall, redemption and church.

81 See also Richard 1992:104-110, with reference to insights derived from Stanley Hauerwas. 


\section{BIBLIOGRAPHY}

Ackermann, DM 1996. On hearing and lamenting: Faith and truth telling. In: Botman, HR \& Petersen, RM 1996. To remember and to heal: Theological and psychological reflections on truth and reconciliation. Cape Town: Human and Rousseau.

Ackermann, DM 2001. Tamar's cry: Re-reading an ancient text in the midst of an HIV/Aids pandemic. Stellenbosch: EFSA.

Bauckham, R \& Hart, T 1999. Hope against hope. Christian eschatology at the turn of the millennium. Grand Rapids: WB Eerdmans.

Beker, JC 1987. Suffering and hope. Philadelphia: Fortress Press.

Berkhof, H 1985. Christelijk Geloof. Nijkerk: G.F. Callenbach.

Bosch, David J 1974. Het evangelie in Afrikaans gewaad. Kampen: JH Kok.

Brinkman, M 1995. A theology of life: Open questions. Exchange 24, 176-183.

Brinkman, ME 1999. Sacraments of freedom. Ecumenical essays on creation and sacrament - Justification and freedom. Zoetermeer: Meinema.

Byamugisha, G et al 2002. Journeys of faith: Church-based responses to HIV and Aids in three southern African countries. Pietermaritzburg: Cluster Publications.

Cock, J 1992. Towards the greening of the church in South Africa: Some problems and possibilities. Missionalia 20:3, 174-185.

Conradie, EM 2000. Hope for the earth - Vistas on a new century. Bellville: University of the Western Cape.

Conradie, EM 2002. Resurrection, finitude, and ecology. In: Peters, T, Russell, RJ \& Welker, M 2002. Resurrection: Theological and scientific assessments, 277-296. Grand Rapids: WB Eerdmans.

Conradie, EM 2001. Eschatological dimensions of a theology of life. In: Van Egmond, A \& Van Keulen, D (eds.) 2001. Christian hope in context. Volume 1. Studies in Reformed Theology 4, 163-204. Zoetermeer: Meinema.

De Gruchy, S 2000. How then shall we be saved? Aids community and redemption. Bulletin for Contextual Theology 7:1, 18-20.

Santa Ana, J de 1995. Elements for a theology of life. Exchange 24, 159-175.

Denis, P 2003. Sexuality and Aids in South Africa. Journal of Theology for Southern Africa 115, 63-78.

Dube, MW 2002. Fighting with God: Children and HIV/Aids in Botswana. Journal of Theology for Southern Africa 14, 31-42.

Dube, MW 2003. Culture, gender and HIV/Aids: Understanding and acting on the issues. In: Dube, MW (ed.) 2003. HIV/Aids and the curriculum: Methods of integrating HIV/Aids in theological programmes. Geneva: World Council of Churches.

Dube, MW (ed.) 2003. HIV/Aids and the curriculum: Methods of integrating HIV/Aids in theological programmes. Geneva: World Council of Churches.

Dube, MW 2003. Talitha cum! Calling the girl-child and women to life in the HIV/Aids and globalization era. In: Phiri, IA, Haddad, B \& Masenya, M (eds.) 2003. African women, HIV/Aids, and faith communities. Pietermaritzburg: Cluster Publications.

Dube, MW 2002. Theological challenges: Proclaiming the fullness of life in the HIV/Aids and global economic era. International Review of Mission 91, 535-545. 
Fröchtling, A 2002. Re(-)membering as dis-membered body: Memoria passionis as a new horizoning on broken ground. Journal of Theology for Southern Africa 114, 43-54.

Gennrich, D (ed.) 2004. The church in an HIV+ world: A practical handbook. Pietermaritzburg: Cluster Publications.

Govinden, DB 2003. 'This is my body broken for you' - Liturgical resources for dealing with HIV/Aids. In: Phiri, IA, Haddad, B \& Masenya, M (eds.) 2003. African women, HIV/Aids, and faith communities. Pietermaritzburg: Cluster Publications.

Govinden, DB 2003. 'This is my body broken for you' - Liturgical resources for dealing with HIV/Aids. In: Phiri, IA, Haddad, B \& Masenya, M (eds.) 2003. African women, HIV/Aids, and faith communities. Pietermaritzburg: Cluster Publications.

Granberg-Michaelson, W 1994. Towards a theology of life. Reformed World 44, 99-110.

Green, EC 2003. How faith-based organizations have contributed to Aids prevention. In: Yamamori, T, Dageforde, D \& Bruner, T (eds.) 2003. The hope factor: Engaging the church in the HIV/Aids crisis. Waynesboro: World Vision Press.

Greyling, C 2001. HIV/Aids and poverty - A challenge to the church in the new millennium. Stellenbosch: EFSA.

Greyling, C 2003. Poverty, HIV/Aids and Aids: Challenge to the church in the new millennium. In: Couture, PD \& Miller-McLemore, BJ (eds.): Poverty, suffering and HIV/Aids: International practical theological perspectives, 117-136. Cardiff: Cardiff Academic Press.

Gutiérrez, G 1973. A theology of liberation. Maryknoll: Orbis Books.

Guy, T \& Gabriel, N s.a. Acting against poverty: An economic justice workbook on HIV/Aids, work, democracy and peace for parish groups. Delmenville: Lumko Institute / South African Catholic Bishops' Conference: Justice and Peace Department.

Haddad, B 2002. Gender violence and HIV/Aids: A deadly silence $\mathrm{n}$ the church. Journal of Theology for Southern Africa 114, 93-106.

Haddad, B 2003. Choosing to remain silent: Links between gender violence, HIV/Aids and the South African church. In: Phiri, IA, Haddad, B \& Masenya, M (eds.) 2003. African women, HIV/Aids, and faith communities. Pietermaritzburg: Cluster Publications.

Hall, DJ 1986. God and human suffering. Minneapolis: Augsburg.

Hall, DJ 1993. Professing the faith. Minneapolis: Fortress Press.

Haught, JF 2000. God after Darwin: A theology of evolution. Boulder: Westview Press.

Isaacs, CD 1998. The church and Aids: Towards a model for ministry to people with HIV/Aids for the Apostolic Faith Mission of South Africa. MTh-thesis. University of the Western Cape.

Kanyoro, MRA 2002. Holistic ways to empower Africa's children and young people. Journal of Theology for Southern Africa 113, 69-78.

Katongole, EM 2001. Christian ethics and Aids in Africa today: Exploring the limits of a culture of suspicion and despair. Missionalia 29:2, 144-160.

Kealotswe, ON 2001. Healing in the African Independent Churches in the era of Aids in Botswana. Missionalia 29:2, 220.

Kgosikwena, KB 2001. Pastoral care and the dying process of people living with HIV/Aids: Speaking of God in a crisis. Missionalia 29:2, 200-219. 
König, A 1988. Bondgenoot en beeld. Gelowig nagedink - deel 4 - oor die wese van die mens en die sonde. Halfway House: NG Kerkboekhandel.

Maimela, S 1991. Traditional African anthropology and Christian Theology. Journal of Theology for Southern Africa 76, 4-14.

Maluleke, TS 2001. The challenge of HIV/Aids for theological education in Africa: Towards a HIV/Aids sensitive curriculum. Missionalia 29:2, 125-143.

Masenya, M 2003. Trapped between two 'canons': African-South African Christian women in the HIV/Aids era. In: Phiri, IA, Haddad, B \& Masenya, M (eds.) 2003. African women, HIV/Aids, and faith communities. Pietermaritzburg: Cluster Publications.

McFague, S 1993. The body of God. An ecological theology. London: SCM Press.

Migliore, DL 1991. Faith seeking understanding. Grand Rapids: WB Eerdmans.

Moltmann, J 1974. The crucified God. New York: Harper.

Moltmann, J 1985. God in creation: An ecological doctrine of creation. London: SCM Press.

Moltmann, J 1996. The coming of God. Christian eschatology. Philadelphia: Fortress Press.

Nicolson, R 1995. Aids: A Christian response. Pietermaritzburg: Cluster.

Nicolson, R 1996. God in Aids. London: SCM Press.

Nicolson, R 2000. God in Aids? - five years later. Bulletin for Contextual Theology 7:1, 10-12.

Niebuhr, R 1941. The nature and destiny of man. A Christian interpretation. Volume I: Human nature. New York: Charles Scribner's Sons.

Pannenberg, W 1994. Systematic Theology. Volume 2. Grand Rapids: WB Eerdmans.

Pannenberg, W 1998. Systematic Theology. Volume 3. Grand Rapids: WB Eerdmans.

Paterson, G 1996. Love in a time of Aids: Women, health and the challenge of HIV. Geneva: WCC Publications.

Pato, LL 1997. Being fully human. From the perspective of African culture and spirituality. Journal of Theology for Southern Africa 97, 53-61.

Phiri, IA 2003. African women of faith speak out in an HIV/Aids era. In: Phiri, IA, Haddad, B \& Masenya, M (eds.) 2003. African women, HIV/Aids, and faith communities. Pietermaritzburg: Cluster Publications.

Pillay, MN 2003. Church discourse to HIV/Aids: A responsible response to a disaster? Scriptura 83, 108-121.

Pobee, John S 1979. Toward an African theology. Nashville: Abingdon Press.

Qakisa, M 2002. Let's talk about sex: Reaching young people through the media in the age of Aids. Journal of Theology for Southern Africa 114, 79-92.

Rakoczy, S 2001. Women in peril of their lives: Feminist ethical perspectives on the HIV/Aids pandemic. Grace and Truth 18:3, 45-56.

Rasmussen, LL 1994. Theology of life and ecumenical ethics. In: Hallman, DG (ed.) 1994. Ecotheology. Voices from South and North, 112-129. Geneva: World Council of Churches.

Rasmussen, LL 1993. Moral fragments and moral community. Philadelphia: Fortress Press.

Richard, L 1992. What are they saying about the theology of suffering? New York: Paulist Press. 
Robra, M 1996. Theology of life - Justice, Peace, Creation: An ecumenical study. Ecumenical Review 48:1, 28-37.

Ruele, MA 2003. Facing the challenges of HIV/Aids in Southern Africa: Towards a theology of life. In: Dube, MW (ed.) 2003. HIV/Aids and the curriculum: Methods of integrating HIV/Aids in theological programmes. Geneva: World Council of Churches.

Ruether, RR 2003. Sexual illiteracy. Conscience 24:2.

Saayman, W 1992. Aids, healing and culture in Africa. Journal of Theology for Southern Africa 78, 41-56.

Saayman, W \& Kriel, J 1992. Aids - The leprosy of our time? Johannesburg: Orion.

Slattery, H 2002. HIV/Aids a call to action: Response as Christians. Nairobi: Paulines.

Surin, K 1986. Theology and the problem of evil. Oxford: Basil Blackwell.

Taylor, John V 2001. Christian presence amid African religion. Nairobi: Acton Publishers. (previously published as Primal vision (SCM Press 1963).

Tillich, P 1957. Systematic Theology. Volume two. Chicago: University of Chicago Press.

Van de Beek, A 1984. Waarom?Over lijden, schuld en God. Nijkerk: Callenbach.

Van de Beek, A 1986. Om de levende God. In: Nogmaals: waarom? Artikelen over en reakties op het gelijknamige boek van dr. A. van de Beek over lijden, schuld en God, 105-123. Nijkerk: Callenbach.

Van der Ven, JA, Dreyer, JS \& Pieterse, HJ 2003. There is no longer Jew or Greek, slave or free, male or female: Empirical research on the church and HIV/Aids in South Africa. In: Couture, PD \& Miller-McLemore, BJ (eds.): Poverty, suffering and HIV/Aids: International practical theological perspectives, 137-154. Cardiff: Cardiff Academic Press.

Volf, M 1996. Exclusion and embrace: A theological exploration of identity, otherness, and reconciliation. Nashville: Abingdon Press.

Weinrich, S \& Benn, C 2004. Aids - Meeting the challenge: Data, facts, background. Geneva: World Council of Churches.

Welch, S 1990. A feminist ethic of risk. Philadelphia: Fortress Press.

Williams, RR 1985. Sin and evil. In: Hodgson, PC \& King, RH (eds.) 1985. Christian theology. An introduction to its traditions and tasks, 194-221. Philadelphia: Fortress Press.

World Council of Churches 1997. Facing Aids: The challenge, the churches' response. Geneva: WCC Publications.

Yamamori, T, Dageforde, D \& Bruner, T (eds.) 2003. The hope factor: Engaging the church in the HIV/Aids crisis. Waynesboro: World Vision Press. 